\title{
DOES LEGAL TRANSPLANTATION WORK? THE CASE OF INDONESIAN CORPORATE GOVERNANCE REFORMS $^{1}$
}

\author{
Harijono \\ Universitas Kristen Satya Wacana Salatiga \\ (harijono@staff.uksw.edu) \\ George Tanewski \\ Faculty of Business and Economics \\ Monash University \\ (george.tanewski@buseco.monash.edu.au)
}

\begin{abstract}
This study examines the impact of corporate governance reforms by analysing the relation between firms' operating performance and key ownership structure and corporate governance variables on a sample of firms listed on the Jakarta Stock Exchange between the periods 1993 to 2007. Contrary to widespread belief that reforms in Indonesia have failed, this paper provides empirical evidence in support of the positive impact of corporate governance reforms. While the impact of family control, the firms' business group affiliation, divergence between cash flow and control rights and political connection are all negatively associated with firms' operating performance (ROA) for the pre-reform period (i.e., 1993-1999), these negative effects disappear during the post-reform period (i.e., 2001-2007), except for family control. More importantly, the relationship between family control and operating performance is negative only when the family's control right exceeds their cash flow right. This study provides some empirical evidence and insights to both regulators and development assistance agencies on the effectiveness of Indonesian corporate governance reforms.
\end{abstract}

Keywords: corporate governance reform, controlling shareholders, firm performance, Indonesia

\footnotetext{
1 This article has been awarded as the third winner of JIEB's Best Paper Award 2011.
} 